\title{
ANTIMICROBIAL EFFECTS OF A MACROPHAGE-DERIVED CYTOTOXIN FROM THE SERUM OF BCG-PRIMED RABBITS (TUMOUR NECROSIS SERUM)
}

\section{LynNe Neale and N. Matthews}

\author{
Department of Medical Microbiology, Welsh National School of Medicine, \\ Heath Park, Cardiff CF $4 X N$
}

\begin{abstract}
Summary. Previous studies have shown that a macrophage-derived cytotoxin, found in high titre in the serum of BCG-primed rabbits, killed malarial parasites and certain tumour cells. In this study, the macrophage cytotoxin was tested for activity against microorganisms other than protozoa. No activity was seen against a range of gram-negative or gram-positive bacteria or against Candida albicans. It is concluded that the macrophage cytotoxin has limited anti-microbial activity, perhaps restricted to certain intra-cellular parasites.
\end{abstract}

\section{INTRODUCTION}

Immunisation with Bacillus Calmette Guérin (BCG) or Propionibacterium acnes (formerly Corynebacterium parvum) can protect against subsequent challenge with antigenically unrelated organisms that include protozoa (Clark, Allison and Cox, 1976; Ortiz-Ortiz, Gonzalez-Mendosa and Lamoyi, 1975), fungi (Sher et al., 1975), bacteria (Adlam, Broughton and Scott, 1972; Baughn, Musher and Knox, 1977) and viruses (Cerutti, 1974), as well as certain transplanted tumours (Halpern et al., 1966; Woodruff and Boak, 1966). This cross resistance is usually considered to be due to activation of the phagocytic and oxidative capacities of the macrophage. However, we noted recently that a macrophage-derived cytotoxin isolated from the serum of BCG- or P. acnes-primed animals (tumour necrosis serum), killed both malarial parasites and tumour cells (Playfair, Taverne and Matthews, in press). This has prompted us to test whether the macrophage cytotoxin can kill microorganisms other than protozoa. The test organisms have been chosen because BCG or $P$. acnes has been shown to induce cross-resistance against them or closely related organisms.

\section{MATERIALS AND METHODS}

Tumour necrosis serum. A New Zealand White rabbit $(2.25 \mathrm{~kg})$ was given one vial of Glaxo percutaneous BCG (50-250 viable organisms/ml of saline) by intravenous injection, followed 14 days later by an intravenous injection of $100 \mu \mathrm{g}$ of endotoxin (Lipopolysaccharide B from Escherichia coli $\mathrm{O} 55: \mathrm{B} 5$, Difco). The rabbit was bled immediately before the endotoxin was given to obtain the control serum and $2 \mathrm{~h}$ after the endotoxin injection to obtain the tumour necrosis serum. When assayed against the mouse L929 tumour cell line (Matthews, 1982), the tumour necrosis serum had a cytotoxin titre of $>10^{5}$ compared with $<10^{2}$ for the control serum.

Test microorganisms. Eleven test strains of nine species of bacteria and one strain of Candida albicans were studied (table). All were obtained from the bacteriology service of the University Hospital of Wales except for the Corynebacterium hofmani strains which were kindly provided by Dr I. Zamiri (Diphtheria Reference Laboratory, Cardiff). They were grown aerobically for $24 \mathrm{~h}$ on blood-agar plates and a stock suspension of each test organism was made in isotonic saline to give an optical density of $0 \cdot 10$ at $620 \mathrm{~nm}$.

Pour-plate assay for microbial growth inhibition. Three-ml volumes of Bacto Antibiotic 
TABLE

Comparison of the effects of saline, control serum and tumour necrosis serum on colony formation by $\mathrm{C}$. albicans and nine species of bacteria

\begin{tabular}{|c|c|c|c|}
\hline \multirow[b]{2}{*}{$\begin{array}{c}\text { Test } \\
\text { microorganism }\end{array}$} & \multicolumn{3}{|c|}{$\begin{array}{l}\text { Mean colony count }( \pm \mathrm{SD}) / \text { dish } \\
\text { in the presence of }\end{array}$} \\
\hline & Saline & $\begin{array}{l}\text { Control } \\
\text { serum }\end{array}$ & $\begin{array}{c}\text { Tumour } \\
\text { necrosis } \\
\text { serum }\end{array}$ \\
\hline $\begin{array}{l}\text { Candida albicans } \\
\text { Escherichia coli } \\
\text { Salmonella sp. } \\
\text { Salmonella agama } \\
\text { Shigella sonnei } \\
\text { Pseudomonas aeruginosa } \\
\text { Listeria monocytogenes } \\
\text { Staphylococcus aureus } \\
\text { Streptococcus faecalis } \\
\text { Corynebacterium hofmani } \\
\text { C. hofmani } 375 \\
\text { C. hofmani } 300\end{array}$ & $\begin{array}{r}211 \pm 10 \\
98 \pm 9 \\
194 \pm 4 \\
58 \pm 3 \\
207 \pm 6 \\
292 \pm 14 \\
459 \pm 15 \\
1088 \pm 43 \\
274 \pm 10 \\
205 \pm 21 \\
201 \pm 14 \\
310 \pm 33\end{array}$ & $\begin{array}{l}210 \pm 7 \\
106 \pm 4 \\
195 \pm 3 \\
26 \pm 6 \\
168 \pm 8 \\
328 \pm 6 \\
507 \pm 34 \\
1042 \pm 56 \\
281 \pm 16 \\
232 \pm 7 \\
222 \pm 19 \\
862 \pm 12\end{array}$ & $\begin{array}{l}216 \pm 10 \\
101 \pm 4 \\
198 \pm 6 \\
48 \pm 11 \\
220 \pm 7 \\
328 \pm 13 \\
468 \pm 21 \\
1065 \pm 37 \\
280 \pm 4 \\
304 \pm 19 \\
209 \pm 21 \\
916 \pm 45\end{array}$ \\
\hline
\end{tabular}

medium 1 (Difco) were melted at $100^{\circ} \mathrm{C}$ and cooled to $56^{\circ} \mathrm{C}$ before $300 \mu$ lof horse serum (Difco) were added. After mixing gently by inversion, the medium was poured into $6-\mathrm{cm}$ plastic petri dishes and immediately $50-200-\mu$ l volumes of saline, control serum or tumour necrosis serum were added with $100 \mu$ lof the microbial suspension (a 1 in 25000 or 1 in 100000 dilution of the stock). The plates were rotated to disperse the organisms and then allowed to set. Colonies were counted after overnight incubation at $37^{\circ} \mathrm{C}$. Each test was done in triplicate. The ratio of volume of tumour necrosis serum to number of organisms was of the same order as that found to be effective against plasmodia.

\section{RESULTS AND DISCUSSION}

Because tumour necrosis serum has high titres of mediators such as interleukin 1 and interferons as well as macrophage cytotoxin, any antimicrobial effect seen with the whole serum could not be directly assigned to the cytotoxin. However, the macrophage cytotoxin has reduced stability after purification; therefore, we decided to use crude serum in the initial experiments with the intention of testing purer cytotoxin preparations if any effects were seen with whole serum. The microorganisms chosen for study were those considered most likely to be susceptible on the basis of published reports on the protection afforded against them by BCG or P. acnes.

In the presence of tumour necrosis serum, there was no reduction in the numbers of colonies of any of the microorganisms tested (table), nor was there an apparent reduction in colony size.

Carswell et al. (1975) noted that the serum of animals challenged with endotoxin 2 weeks after primary intravenous injection of BCG or $P$. acnes caused necrosis of certain transplanted tumours and was cytotoxic to some tumour cell lines in vitro. Because of the relative sensitivity of the in-vitro assays, most studies on the chemistry and biology of the anti-tumour effect have relied upon in-vitro assays. Thus, in the rabbit, the cytotoxin has been shown to be a protein of

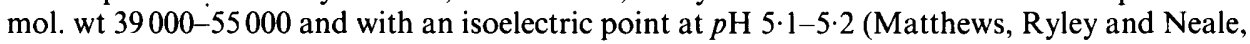
1980; Ruff and Gifford, 1980); it is produced by macrophages (Matthews, 1981; Fisch and Gifford, 1983). Although it was originally thought that the same factor (tumour necrosis factor) was responsible for both in-vivo and in-vitro anti-tumour effects (Green et al., 1976) more recent studies suggest otherwise (Kull and Cuatrecasas, 1981). It is clear, however, that it is the macrophage-derived cytotoxin detected by in-vitro assays that kills malarial parasites (Playfair et al., in press). 
The macrophage cytotoxin had no effect on any of the organisms tested in the present study. These organisms differ from the cytotoxin-sensitive plasmodia in that they were tested whilst growing extracellularly. This suggests that the cytotoxin may be effective only against certain intracellular infections, presumably because it recognises a cell-surface alteration common to both plasmodial infection and malignant transformation. There is a superficial similarity between the cytotoxin and the interferons in terms of activity against both intracellular infections and tumour cells. However, the macrophage cytotoxin has minimal antiviral activity and can be distinguished from the interferons by physicochemical criteria (Matthews, 1979).

In conclusion, this study suggests that the macrophage cytotoxin has limited antimicrobial activity, possibly restricted to certain intracellular parasites.

\section{REFERENCES}

Adlam C, Broughton E S, Scott M T 1972 Enhanced resistance of mice to infection with bacteria following pretreatment with Corynebacterium parvum. Nature New Biology 235:219-20.

Baughn R E, Musher D M, Knox J M 1977 Effect of sensitization with Propionibacterium acnes on the growth of Listeria monocytogenes and Treponema pallidum in rabbits. Journal of Immunology 118:109-113.

Carswell E A, Old L J, Kassel R L, Green S, Fiore N, Williamson B 1975 An endotoxin-induced serum factor that causes necrosis of tumours. Proceedings of the National Academy of Sciences of the USA 72:3666-3670.

Cerutti I 1974 Propriétés antivirales du Corynebacterium parvum. Comptes Rendus de l'Académie Sciences, Paris series D 279:963-966.

Clark I A, Allison A C, Cox F E 1976 Protection of mice against Babesia and Plasmodium with BCG. Nature, London 259:309-311.

Fisch H, Gifford G E 1983 In vitro production of rabbit macrophage tumor cell cytotoxin. International Journal of Cancer 32: 105-112.

Green S, Dobrjansky A, Carswell E A, Kassel R L, Old L J, Fiore N, Schwartz M K 1976 Partial purification of a serum factor that causes necrosis of tumours. Proceedings of the National Academy of Sciences of the USA 73:381-385.

Halpern B N, Biozzi G, Stiffel C, Mouton D 1966 Inhibition of tumour growth by administration of killed Corynebacterium parvum. Nature, London 212:853-854.

Kull F C, Cuatrecasas $P 1981$ Preliminary characterization of the tumour cell cytotoxin in tumor necrosis serum. Journal of Immunology 126:1279-1283.

Matthews N 1979 Tumour-necrosis factor from the rabbit. III. Relationship to interferons. British Journal of Cancer 40:534-539.

Matthews N 1981 Tumour-necrosis factor from the rabbit. V. Synthesis in vitro by mononuclear phagocytes from various tissues of normal and BCG-injected rabbits. British Journal of Cancer 44:418-424.

Matthews N 1982 Production of an anti-tumour cytotoxin by human monocytes: comparison of endotoxin, interferons and other agents as inducers. British Journal of Cancer 45:615-617.

Matthews N, Ryley H C, Neale M L 1980 Tumour-necrosis factor from the rabbit. IV. Purification and chemical characterization. British Journal of Cancer 42:416-422.

Ortiz-Ortiz, L., Gonzalez-Mendoza A, Lamoyi E 1975 A vaccination procedure against Trypanasoma cruzi infection in mice by non-specific immunization. Journal of Immunology $114: 1424-1425$.

Playfair J H L, Taverne J, Matthews N What is tumour necrosis factor really for? Immunology Today (in press).

Ruff M R, Gifford G E 1980 Purification and physico-chemical characterization of rabbit tumor necrosis factor. Journal of Immunology 125:1671-1677.

Sher N A, Chaparas S D, Greenberg L E, Bernard S 1975 Effects of BCG, Corynebacterium parvum and methanol-extraction residue in the reduction of mortality from Staphylococcus aureus and Candida albicans infections in immunosuppressed mice. Infection and Immunity 12:1325-1330.

Woodruff M F A, Boak J L 1966 Inhibitory effect of injections of Corynebacterium parvum on the growth of tumour transplants in isogenic hosts. British Journal of Cancer 20:345-355. 